\title{
FAMILY-OWNED NEWSPAPERS: FILLING NICHES IN LOCAL U.S. COMMUNITIES
}

\author{
Angela Powers \\ Kansas State University \\ Ardyth Broadrick Sohn \\ Henderson, Nevada \\ Jane Briggs-Bunting \\ Michigan Coalition for Open Government
}

\begin{abstract}
Revised and resubmitted to the Journal of Media Business Studies, Spring 2014. This paper received funding from the Office of Research and Sponsored Programs and the A.Q. Miller School of Journalism and Mass Communications at Kansas State University. A version was presented at the International Communication Association, London, 2013.
\end{abstract}

ABSTRACT Since small town newspapers are facing increased competition and technological changes that are threatening their survival, the purpose of this paper was to analyze the strategy-making activities of these organizations from an ecological perspective. Findings indicate that family-owned newspapers were finding stability in retaining their core print businesses while migrating content to the web. Too many variations from the norm appeared to weaken financial footholds and were often eventually abandoned. Such behaviors indicate a rationale for upholding a "tried-and-true" approach in newspapers. While profits may fluctuate, the uncertainty that occurred with variation seemed to play a role in increasing the threat of failure for these small, family-owned newspapers.

KEY WORDS media ecology, newspapers, news media, niches, family newspapers, organizational ecology

Copyright ( 2014 Journal of Media Business Studies. Angela Powers, Ardyth Broadrick Sohn and Jane Briggs-Bunting, "Family-Owned Newspapers: Filling Niches in Local U.S. Communities", 11(2): 00-00 (2014). 
Newspapers in many communities locally and globally flounder as they hold on to their past in search of a survivable future (Patel, 2010). Trade literature suggests, however, hometown newspapers may be faring better than some of their metropolitan counterparts (Berkshire Hathaway, 2013) due to an increased focus on content unavailable elsewhere. With increasing attention being paid to such newspapers as evidenced by recent purchases of Buffett and Bezos (Bercovici, 2013), a need exists to analyze the strategies and strengths of smaller or family-owned newspapers which are often overlooked in media research (Gomez-Mejia, Nunez-Nickel and Gutierrez, 2001).

While family newspapers are in many ways addressing the changing media landscape, they have historically been slow to innovate (Picard, 2011). Picard says there may be good reason for caution. If newspapers were to completely digitize, for example, advertisements might generate only five to ten percent of what they had generated in print. Rather than take such risk, newspapers have often adoped a conservative approach and adhered to the status quo, leaving organizations such as Google News, KyPost.com, and Buzzfeed.com, to innovate and attract younger and more diverse audiences (Patel, 2010). With such trends in mind, the purpose of this paper is to analyze strategy making in family-owned newspapers by using organizational ecology as a framework to better understand the forces that shape the structures of these newspaper companies. According to Hannan and Freeman (1989, p. 13), ecological analysis is appropriate when organizations are "subject to strong inertial pressures and face changeable, uncertain futures," as is the case with newspapers today.

\section{LITERATURE REVIEW}

While few studies exist on the ecology of local news organizations, Carroll and Hannan (2000) were one of the first to use organizational ecology (OE) to construct life histories of large newspapers operating in urban areas in the U.S. They analyzed the founding (or initiation) of publications and mortality (or cessation of publications) and discovered that start-up media often occurred as a result of environmental events such as political turmoil, or the need to fill a niche for particular information. Managers of these new organizations were not always rational in their decision to start, operate and end businesses, however. Inertial tendencies were strong especially for the older and larger organizations. When the environment changed, organizations often became incompatible and were eventually replaced by newer entities better suited to meet external demands.

Lowrey (2012) also used OE to study media in one urban area and found new media first sought an area of specialization (a niche), and then migrated toward a safe and familiar routine in search of financially stability. The major media in the city viewed their niche as broad but were having mixed economic results. The competing specialized media 
were aggressive in their use of social media. Only the more institutionalized media, however, had a clear fit with their populations.

Powers and Sohn $(2012,2013)$ studied a family-owned company in a large rural state market and found that in the midst of change, the newspaper was seeking to maintain a former niche while establishing a new one and struggled with resources needed for two markets (local and national). A diverse variety of entities were introduced, indicating an instrumental process where the organization was pursuing an optimized fit within a changing environment. Most of these variations proved detrimental to financial sustainability, however, and were eventually disbanded.

Organizational ecology, as previous media studies indicate, provides a useful framework for analyzing change in newspaper organizations. According to Hannan and Freeman (1989), it allows for systematic analysis over time of populations that contain large, powerful organizations within communities at both the local, national and international level. According to the model, long-term change or variation occurs through selection rather than adaptation. Innovation and new competitors emerge and are impacted by variables within three stages: variation, selection and retention, as shown in Figure 1.

Figure 1: Stages of Evolution in Media

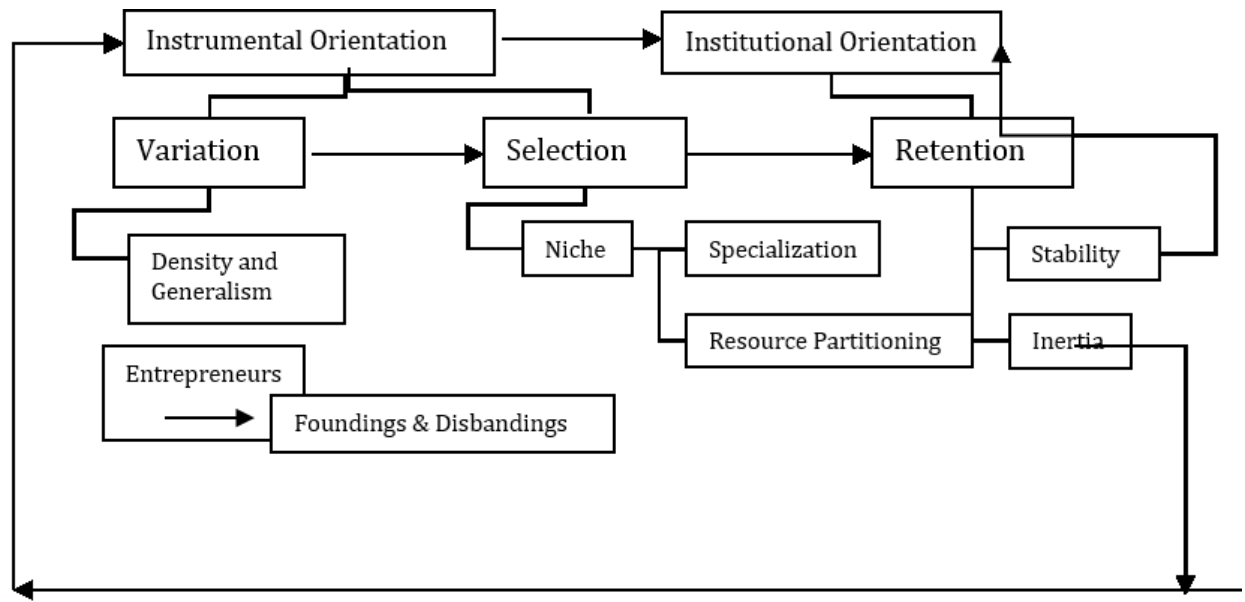


In the variation stage, founding and disbanding (startup and shutdown) of practices and organizations occur, increasing departures from routine or tradition. According to the theory, a variety of practices or organizations are needed so that some are selected and others eliminated. These diverse variations are likely to develop in the fertile margins left open by a dense and concentrated (media) industry focused on standard operating procedures. When this center is dense and only a few companies dominate, the process of change is disruptive, however, and elevates the rate of mortality for all companies in a "survival of the fittest" scenario. The concentrated center is steadfast in upholding a generalist approach and the status quo (Pfeffer and Salancik, 2003), while entrepreneurs introduce specialization.

In the selection stage, specialization survives and innovations settle into niches. Such innovations coalesce and flock together in populations where companies and society eventually develop shared understandings. For example, newspaper pay walls become common and accepted practices resulting in benefits for both new and legacy media. In addition, innovations such as Craigslist institutionalize, causing resource partitioning of advertising dollars as they are drawn away from the concentrated industry. Once the market becomes less concentrated, market resources become partitioned. In response, the center of a market (legacy media) also exploits innovations and economies of scale in order to survive.

In the retention stage, long-term survival of entities occurs, and the environment is stable. A relatively few selected variations gain stability and reach the retention stage. Uncertainty is reduced for these organizations and practices, and they become "taken-for-granted" and held in place by shared understandings and interdependencies (Carroll \& Hannan, 1995, 2000). The risk of failure that was so high initially declines as organizations age. However, liabilities of aging eventually recur due to internal inefficiencies and inertia that arise, and the process of change begins anew.

In addition, as organizations move from variation through selection and retention, their orientation shifts from a strategic, instrumental orientation toward a more stable institutional orientation. An instrumental approach reflects strategic pursuit of an optimized fit within changing environmental niches over time. New businesses or strategies that better meet consumers' needs are introduced. Such environments are training grounds for entrepreneurs as new ideas and businesses compete and change the status quo (Hannan and Freeman, 1989, pp. 56-57).

Moving from an instrumental to an institutional orientation, companies become grounded in tradition and stability. Once companies become institutional, they adhere to the idea that change is disruptive, and reliable organizations are more likely to survive. Institutionalism has clear advantages because powerful organizations protect each other 
and the status quo (Hannan and Freeman, 1989). Disadvantages include inertia and resistance to change (DiMaggio \& Powell, 1991).

$\mathrm{OE}$ also indicates different types of organizations such as family companies change in different ways. Family-owned businesses make up about one third of Fortune 500 companies and possess unique characteristics (Perman, 2006). According to Ward (2004), strengths of a family business include commitment, knowledge continuity, reliability and pride. Leach and Leahy (1991) indicate that family-owned companies often perform better than public companies on a number of growth measures such as sales and profits. Furthermore, Anderson and Reeb (2003) found that CEOs who were family members exhibited a positive relation to profitability variables.

Weaknesses, on the other hand include the inability of most family firms to continue after the third generation (Neubauer and Lank, 1998). Over time, issues of informality, lack of discipline, and inefficient governance may impact success. Furthermore, the younger generation struggles with ambivalence and avoids the topic of change. While change is needed, the motivation levels of family members differ, and the need to honor past traditions can impede progress. In fact, Gersick, Davis, Hampton, and Lansberg (1997), found that in family companies considering transitions and changes, the senior generation senses its cause is noble and important and that only he or she is uniquely qualified to accomplish such tasks.

Based on the literature, the following questions are addressed regarding how family-owned, small town newspapers are addressing change within their organizations and communities:

RQ1: Are family newspapers operating according to the stages of variation, selection, and retention?

RQ2: Are family newspapers pursuing an instrumental or institutional approach?

\section{METHODOLOGY}

This study examined three small-town, family-owned newspapers between 2005-2012 as the industry faced transitions from print to digital formats. This convenience sample fit the criteria of OE theory allowing us an exploratory look at strategy making in newspapers as they addressed the ability to survive in local communities. Each newspaper had been owned by their current family for more than 50 years and had been founded in their communities for nearly 100 years. A family company was defined as a majority of voting shares owned by one family, or when the CEO perceives it to be a family business, or when at least one member in the management group comes from the family, (Brandt, E., Kull, P., Bjorkdahl, J., 2007). Family-owned newspapers were chosen because of their unique characteristics and because, according to Gomez- 
Mejia et al. (2001), they can be (1) simpler organizations in terms of size, product differentiation and ownership, (2) in the same industry and country allowing for the control of extraneous variable, (3) and their performance data in terms of circulation are readily available.

An exploratory study was undertaken because according to Nordqvist, Hall and Melin (2009), this approach is interpretive in nature and useful as a building block for deeper insights into media organizations. Exploration involved attending meetings and interviewing CEOs about their strategic planning on issues such as content development, revenues and acquisitions. Family members held the CEO positions of editor and publisher. In-depth interviews were conducted both at the newspapers and by phone. Interviews were semi-structured and lasted approximately 60 minutes on average. In addition to interviews, researchers attended strategic management meetings and had the opportunity to ask follow-up questions. A total of six meetings were attended.

\section{RESULTS}

Table 1 provides descriptions of the newspapers analyzed. The first newspaper was a small weekly with a year-round population of about 3,000 . It was founded in 1878 , and for more than fifty years had been owned by one family. This paper had a husband and wife team that oversaw the editorial and advertising sections with a small staff of about thirteen. It published an additional weekly newspaper between May and September for residents and tourists who heavily visited a nearby vacation island. Interestingly, its circulation was 4,985, including summer residents. The second newspaper was a small daily in a city of about 54,000. For about 100 years, this company had primarily published print newspapers. Later holdings included a commercial lithographic printing company and visual art services. Circulation was 8,300; and staff size was 57. The third newspaper was a larger daily in a city of 89,000. For more than 120 years, this company had published a newspaper in what was considered a "highly-ranked newspaper state." Holdings also included a broadcast television station, cable station, magazines as well as a software and broadband company. Circulation was 17,225 , and staff size was 141 .

\section{Variation}

According to the OE model, a diverse variety of entities are needed so some forms and practices are selected and others are eliminated (Baum and Singh, 1994). The editor of the first weekly newspaper said innovations were minimal and that poor corporate decisions were redefining the newspaper away from its role as a social institution. Resources for variation and new practices were also limited, rather, efforts focused on quality of reporting. Writers were given the freedom 
and flexibility to enterprise stories and own their beats and geographic areas, while the newspaper provided the leadership, structure, and tools for promoting a variety of content. The paper was also experimenting with online subscription security, comment sections to online stories and other social media, as well as various forms of delivery on devices such as Kindle and mobile phones.

Table 1: Descriptions of Newspapers

\begin{tabular}{|l|l|l|l|}
\hline & Newspaper 1 & Newspaper 2 & Newspaper 3 \\
\hline Type & Small Weekly & Small Daily & Larger Daily \\
\hline Population & 3,000 & 54,000 & 89,000 \\
\hline Founded & 1879 & 1915 & 1892 \\
\hline Years in Family & 50 & 99 & 122 \\
\hline Circulation & 4985 & 8300 & 17,225 \\
\hline Staff Size & 13 & 57 & 141 \\
\hline $\begin{array}{l}\text { Interviews } \\
\text { Conducted }\end{array}$ & 2 & 3 & 3 \\
\hline $\begin{array}{l}\text { Meetings } \\
\text { Attended }\end{array}$ & 2 & 2 & 2 \\
\hline
\end{tabular}

For the second newspaper, innovation also centered on the Internet. Free access to online content was introduced initially. However, this initiative was disbanded early on. The editor indicated local audiences and advertisers were limited while ad space online was not, so advertisers did not value online advertising and did not want to pay for it. Other entities introduced included increased enterprise reporting online, streaming content such as high school video, searchable databases, text message alerts and daily deals for Internet customers.

For the third newspaper, an even greater variety of media entities had been put to trial. Purchases and developments included cable and broadcast stations, along with a software company that created a content management system for interactivity. When the company sold the software company, the newspaper continued to use the content management system developed for its online sites. The company also produced several successful magazines and provided printing services to clients that contributed to revenues. However, as newspapers began cutting back, these revenues declined. Meanwhile, promoting online products (representing only 10 percent of the print subscribers at the time), its online presence continued to grow. It planned to move subscribers from print to online editions to save printing and mailing costs and provide faster delivery to out-of-town and out-of-state residents. Discussion indicated quite a bit of trial and error, which was indicative of a newspaper evolving through variation and selection stages. 


\section{Selection}

In the selection stage, the first newspaper was also moving subscribers from print to online to cut costs and provide faster out-of-town delivery for its large vacation population. The newspaper created identical print and online products, but charged for both. Giving free online service to print subscribers would have "defeated the purpose," according to the editor, since subscribers would not have been motivated to drop the print version, thereby reducing mailing costs. While the newspaper did not care which one was bought at the time, the hope was that subscribers would eventually move online as they became used to the format.

For the second newspaper, the free online edition was disbanded and a pay wall was introduced in 2009. The editor stood firm in the belief that content had value, and since customers had paid for the newspapers for hundreds of years, they would continue to pay for the content online. Moreover, since the newspaper was a family business, there were no dividend requirements and no shareholders to please. The editor's was at liberty to commit to the print product along with a pay wall in order to succeed. While there were no close substitutes or major competitors locally, the editor indicated free online competition was a threat, including Craigslist, Facebook and Twitter. Craigslist, in particular, had negatively impacted the revenues of classified ads. Regardless, the editor was not interested in giving away news content on Facebook or Twitter and had no intention of providing volumes of free material online, although some free information was provided to entice audiences.

For the third newspaper, once the recession hit in 2010, the profitability of the innovations became of key concern. At this stage, decisions had been made to disband and/or sell off many entities including broadband and cable in order to reap whatever profits were available. Media convergence including a broadcast television platform was a venture they hoped would pay off reaching a major portion of the region with print and video; however, it was never profitable. As the manager stated, "It was all sold in a fire sale," indicating a disbanding of variations, and a retention of the principal print property.

\section{Retention}

The first newspaper's website was to become the pillar of operations. It posted the complete, paginated print edition on the Web, so the products were identical. Both versions required payment. They took advantage of digitization with HTML formatting, PDF viewing, Flipview, PageView, and search capabilities. They allowed free online access to all advertising and calendars of events. In addition, anything offered on the Web that was not offered in print was provided free. This included additional photographs and scanned public documents that supplemented stories.

The same advertising appeared in both print and online editions. However, they reduced the price of the online edition as an incentive to switch and in relation to reduced distribution costs. All advertising 
continued to be generated in the printed product, but it was all posted online as display ads and linked to advertiser Web sites, e-mails and telephone numbers. They did not charge for access to online ads or for the news archives after four weeks. Four weeks was selected because it took distance subscribers two to three weeks to receive the mail version. To stay solvent, they charged the entire online overhead against paid online subscriptions.

The pay model consisted of a charge of $\$ 52$ for print subscriptions and $\$ 35$ for online subscriptions, with no discounts for combinations because they did not give any incentives for staying with print. Seasonal subscribers could, however, switch over to digital when away and back to print upon return. The editor believed the pay model was validated by the failure of daily newspapers to make much money by giving away content. They received few complaints about having to pay for both print and online. One struggle was that, according to the editor, in much of rural America, most local subscribers only had dial-up Internet service; so online subscribers lived primarily in cities and out of state. They believed that online readership would continue to grow, as more readers would get high-speed Internet service. The online subscription list for their newspaper was about $10 \%$ of its print list and was expected to grow.

Retention activities for the second newspaper focused on the print product. The editor indicated that the newspaper was able to conduct business much as it always had and was financially stable as a result. They had not taken on debt for major acquisitions or expansions as large conglomerates had done in the early 2000s. The editor noted that its niche was and continued to be mature adults in the community, ages 25 and older, who were serious thinkers, well-educated and higher paid. $\mathrm{He}$ said the niche was the same for both the online and print products. The online target used to be younger, he indicated, but that had changed. In terms of content niche, it was local news and information. Because the community was somewhat transient with large military, university, and government research populations, the editor indicated the daily newspaper was by far the leader in providing local information for readers eager to learn about their community. According to the editor, 25 years ago, content would have been less focused on local news and more on national/international news, but today that information is readily available and is not the niche the newspaper was filling.

The editor additionally indicated that while the newspaper remains a generalist in its niche, competitors were free to fill in the gaps with more specific targets in terms of content or audience. For example, the college newspaper competitor was targeting a college audience and advertiser, while having little impact on the niche and institutional positioning and stability of the local daily.

For the third newspaper in the retention stage, focus was on the newspaper product. Its software company that was marginalized by larger companies was sold. In addition, by selling off broadcast, cable and broadband entities, the company was, according to the manager, "left 
with the hardest part of the equation...how to make the newspaper profitable." The decision to sell cable, broadcast and broadband, which were a large part of innovation plans, was difficult. For profitability, these properties were sold at their peak at record prices. For the company, though, the sales meant that the enterprises that enabled media convergence went away. Plans for the newspaper were ambiguous, and while it was still profitable, the family was looking for alternative sources of funding.

\section{Institutional v. Instrumental}

The first two newspapers were most indicative of an institutional approach where they were secure within the standings of their communities and where their practices were routine. The publisher of the weekly newspaper had been selling and writing for the weekly island newspaper first owned by his father, a retired journalism professor, since 1960. When the publisher and his wife decided to commit to the news business as a career, they purchased two additional weekly newspapers in the region in 1973. The husband and wife team were committed to promoting "free and critical thought as a way to define democracy, competency, honesty, and readability." However, this paper also viewed itself as "drifting toward a search for economic salvation, away from the intellectual mission, and toward a more pedestrian and non-professional practice of our craft." According to the editor, "newspapers, like churches and parents, are drifting from being sort of a moral authority in the community."

The publisher said his editorial staff held true to traditional journalistic standards and promoted ethical and professional behaviors, sound reporting practices, along with strong relationships among readers and sources. They hired good writers, good personalities, and people with some sense of its mission and people who were self-motivated to cover the local community. Their product had no close substitutes. The region was lightly populated and not attractive to publishers like Patch.com and generally overlooked by other media within the state and nation. The newspaper "owned" its market. The local radio stations were "rip and read" establishments, and there were no local or nearby television outlets.

The second newspaper's approach was also indicative of an institutional approach. This newspaper operated from a position of strength regarding its niche. Management focused on strategies that had been used for a long time. It also had a group of peers that helped in the decision-making process including network of media outlets owned by various members of the family. While they were each independently owned, they shared ideas and staked small amounts of ownership among family members. Reliance on professional organizations was also important in strategy making, including industry journals and organizations. This institutional approach was contributing to a stable media environment in the local community. 
The third newspaper's approach, on the other hand, was instrumental in approach and vigorously striving to find a best fit between its readers and itself through innovation, experimentation and entrepreneurship. It was a fourth-generation family newspaper with a philosophy that it would rather have "tried and failed than to have allowed a competitor to take over." They hired experts to develop media convergence within the company. Their expansion into broadband enabled the company to focus on community journalism and interactivity. This company viewed itself as a trendsetter in multi-media journalism. They were creating digital communities online with the first being in the content area of health. They were moving to create other online communities related to energy and environmentalism when the recession began taking a heavy toll. They were also writing software and selling multi-media programs to other newspapers, all the while engaging community through staff and reader blogs with online stories providing comment sections.

Throughout innovations, the owners of the larger daily newspaper resisted a pay wall. About 40 percent of their general online news site attracted local audience, while about 80 percent of their online sports attracted a global audience. The third newspaper's philosophy had been that "if we take care of our city, our city will take care of us." As the manager stated, this was not so true anymore because towns have become corporatized. They were unsure of the future. While the family was committed to the newspaper, it did not want its livelihood connected to the paper anymore. There had been discussions about the possibility of the newspaper being taken over by a non-profit, a university or a foundation. The instrumental approach of innovation and best fit, while trendsetting, often proved unprofitable, increasing instability.

\section{CONCLUSION}

In terms of organizational ecology (OE) as outlined by Hannan and Freeman (1989), all newspapers were in the midst of change, seeking to maintain a former niche while establishing new niches, and struggling with decreasing revenues. These newspapers prided their adherence to journalism traditions; however, managers expressed concerns about their financial futures. Findings indicate they were primarily finding success in retaining print operations while migrating content to the web. Too much variation from their core business of producing a newspaper appeared to weaken financial footholds, and such innovations were eventually abandoned. According to Hannan \& Freeman (1989), such behaviors indicated a rationale for staying with the "tried-and-true." While profits fluctuated, the uncertainty that occurred with variation seemed to play a role in increasing the threat of morbidity for these family-owned newspapers. The newspaper manager whose company had been most innovative and instrumental spoke most candidly of financial peril and the lack of sustainability. 
This study also indicated newspapers could be both instrumental and institutional in their approaches. These news operations, particularly the larger newspaper, often behaved in instrumental ways - where they tried to find a best fit between products and readers. In fact, the study indicated all newspapers were in better touch with audiences because of web metrics and social media. Nevertheless, the newspapers primarily behaved in institutional ways - which, according to Hannan and Freeman (1989), overlook commercial environments, adhere to processes of official institutions and emulate the forms and practices of other similar media outlets to appear legitimate.

Family ownership also came into play and appeared to have an impact on strategies to stay the safe course. Gersick et. al. (1997), found that family members in companies considering transitions and changes are often resistant. The smallest daily paper, for example, proudly targeted same niche for the past one hundred years. Stability and familiar approaches continued to provide profitability and enabled the paper to meet its goals and mission. Strong family and business ties with community leaders also allowed for a level of safeguard. Additionally, strong family ties and an assortment of family business ventures such as the streaming of high school sports supported the ability of this newspaper to continue business as usual. The mission of the paper was to provide local news and information, as had always been the practice, supporting the notion that family companies believe their traditions are noble and that they are uniquely qualified to maintain an institutional presence within the community by fostering relationships among community leaders and audiences. According to OE, family ownership and reliable organizations are often more successful (Poutziouris, 2002).

Results also indicate, however, that while we may be able to look toward small, family newspapers for stabilization, they are not where potential entrepreneurs can look for innovation. Newspapers in this study rarely left the comfort of their institutional histories for very long. Virtually no major risks or unique entrepreneurial strategies were either introduced and/or retained by any of the three companies. What we may come to expect from small family newspapers is a preserved working history of our baseline business model as media evolutions occur elsewhere. Indeed, according to organization ecologists, innovations are most likely to develop in the fertile margins left open by institutionalized centers focused on retention and stability (Pfeffer and Salancik, 2003). As such, new management models of content, delivery or platforming will most likely come from outside the newspaper industry. 


\section{REFERENCES}

Anderson, R. C., \& Reeb, D. M. (2003). Founding-family ownership and firm performance: Evidence from the S\&P 500, Journal of Finance. LVIII (3). 1301-1328.

Baum, J. C., \& Singh, J. V. (1994). Organizational hierarchies and evolutionary processes: Some reflections on a theory of organizational evolution. New York: Oxford University Press.

Bercovici, J. (2013, December 12). Jeff Bezos: I had to be talked into buying the Washington Post. Forbes. Retrieved from www.forbes.com.

Berkshire Hathaway buys Oklahoma newspaper. (2013, February 15). The Daily Progress. Retrieved from http://www.dailyprogress.com/news/article_c5937290-7fe7-11e2-a4610019bb30f31a.html

Brandt, E., Kull, P., \& Bjorkdahl, J. (2007). Acquisition strategy: A case study within family businesses. Unpublished doctoral, Jonkoping University, Jonkoping, Sweden.

Carroll, G. R., \& Hannan, M. T. (1995). Organizations in industry. New York: Oxford University Press.

Carroll, G. R., \& Hannan, M. T. (2000). The demography of corporations and industries. Princeton, N. J: Princeton University Press.

DiMaggio, P. J., \& Powell, W. W. (1991). The new institutionalism in organizational analysis. Chicago: The University of Chicago Press.

Gersick, K.E., Davis, J.A., Hampton, M.M. \& Lansberg, I. (1997). Generation to generation: Life cycles of the family business. Boston Massachusetts: Harvard Business School Press.

Gomez-Mejia, L. R., Nunez-Nickel, M., \& Gutierrez, I. (2001). The role of family ties in agency contracts. Academy of Management Journal, 41 (1) 81-95.

Hannan, M. T., \& Freeman, J. (1989). Organizations and social structure. Organizational ecology (pp. 3-27). Cambridge, Harvard University Press.

Leach, D., \& Leahy, J. (1991). Ownership structures, control type classifications and the performance of large British companies. Economic Journal, 101, 1418-1437.

Lowrey, W. (August 2012). Organization ecology and emerging media: A case study. Paper presented at AEJMC, Chicago.

Moos, J. (2012, May 17). Media general to sell most of its newspapers to Warren Buffett's Berkshire Hathaway. Retrieved from http://www.poynter.org/latestnews/mediawire/174282/media-general-to-sell-most-of-its-newspapers-to-warrenbuffetts-group/

Neubauer, F., \& Lank, A. G. (1998). The family business: Its governance for sustainability. New York: Rutledge.

Nordquist, M., Hall, A., \& Melin. (2009). Qualitative Research on Family Businesses: \{the\} Relevance and Usefulness of the Interpretive Approach. Journal of Management and Organization, 15, 294-308.

Patel, S. (2010). The survival of newspapers in the digital age. The New York University Stern School of Business. Retrieved from www.stern.nyu.edu 
Perman, S. (2006, February 13). Taking the pulse of family business. Retrieved from http://www.businessweek.com/stories/2006-02-13/taking-the-pulse-of-familybusinessbusinessweek-business-news-stock-market-and-financial-advice

Pfeffer, J., \& Salancik, G. R. (2003). The external control of organizations: A resource dependence perspective. Stanford, CA: Stanford University Press.

Picard, R.G. (2011). The economics and financing of media companies. New York: Fordham University Press

Poutziouris, P. Z. (2002). The financial affairs of smaller family companies. In D. Fletcher (Ed.), Understanding the small family business. (pp. 111-126). London: Rutledge.

Powers, A., \& Sohn, A. (September 2012). Toward an organizational ecology model of news media: A case study of family-owned companies. Paper presented, Sweden: Jonkoping International Business School.

Powers, A., \& Sohn A. (2013). Newspapers adapting and surviving in two rural states. Online Journal of Rural Research and Policy, ojrrp.org/journals/ojrrp/issue/view/210

Pryne, E. (2009, March 7). Newspapers make move to online only. Retrieved from http://seattletimes.com/html/businesstechnology/2008823971_onlinepapers07.html

Ward, J.L. (2004). Perpetuating the family business. New York: Palgrave Macmillan. 